\title{
PENGEMBANGAN MULTIMEDIA INTERAKTIF UNTUK PERUSAHAAN JASA
}

\author{
Ihda Neni Nur Azizah \\ Nujmatul Laily \\ Universitas Negeri Malang \\ ihdanenina@gmail.com
}

\begin{abstract}
Research of Interactive Multimedia Development on Accounting Subject of Accounting Cycle for the Service Company aims to maximize the media that has been provided by the school, and expected can motivate student in study so that the learning objects can be achieved. The trial of this interactive multimedia development is given to the ten grade of Accounting SMK muhammadiyah 2 Malang. Data analysis techniques used include: response subject experts, media, individual testing, small group testing, and large group testing using eligibility criteria instructional media and student learning outcomes by using pretest and postest. It mean that interactive multimedia can be used as a media in the learning process.
\end{abstract}

Keywords: Development, Interactive Multimedia, Accounting

\begin{abstract}
Abstrak: Penelitian pengembangan multimedia interaktif pada mata pelajaran akuntansi Pokok Bahasan Siklus Akuntansi Perusahan Jasa ini bertujuan untuk memaksimalkan media yang telah disediakan oleh sekolah, dan diharapkan dapat memotivasi siswa dalam belajar sehingga tujuan pembelajaran dapat tercapai. Pengembangan multimedia interaktif ini diuji cobakan kepada siswa kelas $\mathrm{X}$ Akuntansi di SMK Muhammadiyah 2 Malang.Teknik analisis data yang digunakan antara lain: tanggapan ahli materi, media,uji coba perorangan, uji coba kelompok kecil, dan uji coba kelompok besar dengan menggunakan kriteria kelayakan media pembelajaran dan hasil belajar siswa dengan menggunakan pretes dan postes. Dari hasil tersebut dapat disimpulkan bahwa multimedia interaktif telah layak dan dapat digunakan sebagai media dalam proses pembelajaran.
\end{abstract}

Kata kunci: Pengembangan, Multimedia Interaktif, Akuntansi.

Pendidikan merupakan salah satu bagian yang tidak terpisahkan dari proses pendewasaan manusia dan memiliki peran yang besar bagi pengembangan ilmu pengetahuan dan teknologi. Pendidikan dapat diartikan sebagai suatu kegiatan yang disusun secara sitematis dan simetrik yang terarah kepada tujuan yaitu terbentuknya kepribadian peserta didik karena proses pendidikan berlangsung secara berkesinambungan (prosedural) (Tirtarahardja, 2010 : 34). Teknologi pendidikan merupakan penerapan teknologi yang disusun menggunakan 
pendekatan yang logis, sistematis dan ilmiah dalam kegiatan pendidikan dan pengajaran (Danim, 2008 : 6). Teknologi pendidikan merupakan pembelajaran dan etika dalam penyampaian menggunakan fasilitas pembelajaran dan peningkatan kinerja dengan kreatiifitas yang dimiliki. Penggunaan teknologi dalam bidang pendidikan tercermin dalam pemanfaatan media khusunya media yang berbasis multimedia dalam proses belajar mengajar yang selalu berkembang setiap tahunnya.

Proses belajar mengajar merupakan proses komunikasi, yaitu proses penyampaian pesan dari sumber pesan melalui media tertentu kepada penerima pesan. Pesan yang disampaikan adalah pengetahuan dan pemahaman yang disesuaikan dengan karakter masing-masing siswa (Winarno, 2014 : 4). Pengetahuan tersebut berupa materi yang telah di susun dalam kurikulum, sumber pesan tersebut adalah guru atau siswa. Proses belajar mengajar bisa berlangsung secara tepat dan dapat terlaksana dengan baik jika media pembelajaran memiliki kualitas yang baik pula. Peran guru sebagai fasilitator bagi siswa di tuntut untuk kreatif dan inovatif, guru setidaknya dapat mengoperasikan fasilitas yang telah disediakan oleh sekolah seperti komputer dan LCD yang dapat memudahkan guru dalam penyampaian materi sehingga dapat menciptakan pembelajaran yang efektif dan efisien, seperti yang diungkapkan oleh Arsyad (2014: 2) bahwa guru di tuntut agar mampu menggunakan alat-alat yang disediakan oleh sekolah, dan tidak tertutup kemungkinan bahwa alat-alat tersebut sesuai dengan perkembangan dan tuntutan zaman. Multimedia merupakan salah satu media yang dapat memudahkan guru dalam proses belajar mengajar.

Berdasarkan hasil wawancara yang dilakukan di SMK Muhammadiyah 2 Malang, peneliti menemukan permasalahan yang berkaitan dengan proses pembelajaran kelas $\mathrm{X}$ di SMK Muhammadiyah 2 Malang, guru masih menggunakan metode konvensional selama memberikan materi pembelajaran, hal tersebut mengakibatkan siswa kurang termotivasi untuk mendengarkan penjelasan guru, minat belajar siswa mulai menurun setelah beberapa saat pelajaran berlangsung, hal ini dapat dilihat dengan adanya siswa yang mengobrol dan membuka buku selain Akuntansi pada saat guru menjelaskan.

Fasilitas yang di miliki SMK Muhammadiyah 2 Malang cukup lengkap, sekolah telah menyediakan LCD projector di masing-masing kelas, sekolah juga telah memiliki lab komputer yang dapat digunakan untuk membantu dalam proses belajar mengajar, akan tetapi guru belum memanfaatkan fasilitas tersebut dengan maksimal, selain itu karena keterbatasan kemampuan guru dalam membuat media pembelajaran yang menarik dan dapat meningkatkan motivasi belajar siswa. Pada saat kegiatan belajar mengajar guru juga sesekali menggunakan media yang ada, guru menggunakan power point dalam proses pembelajaran, akan tetapi power point yang telah dibuat guru kurang bervariasi dan kurang menarik sehingga siswa merasa bosan dan tidak memperhatikan penjelasan guru, selain itu power point hanya berupa slide show yang monoton dan tidak ada umpan balik yang membuat siswa lebih tertarik untuk menyimak materi yang di sajikan.

\section{METODE}

Penelitian ini dikategorikan sebagai penelitian dan pengembangan (Research and Development). Tujuan dari penelitian pengembangan ini adalah 
menghasilkan produk berupa pengembangan Multimedia Interaktif pada mata pelajaran akuntansi pokok bahasan siklus akuntansi perusahaan jasa dan menguji kefktifan dari hasil belajar siswa yang diperoleh dari pretes dan postes.Penelitian pengembangan multimedia interaktif telah banyak dilakukan dalam penelitian sebelumnya.Dalam materi menyusun jurnal penyesuaian perusahaan dagang, multimedia interaktif di rancang menggunakan autoplay media studio 8 yang dikemas dalam CD (Compact Disc). Kelebihan pembuatan produk menggunakan autoplay media studio 8 adalah di dukung dengan berbagai software, ukuran serta kualitas yang lebih baik, serta dapat digunakan untuk membuat CD Interaktif, dapat ditampilkan di banyak media, dan dapat mengimpor hampir semua gambar dan file-file audio sehigga dapat lebih hidup. Gambar 1 menunjukkan alur penelitian dan pengembangan.

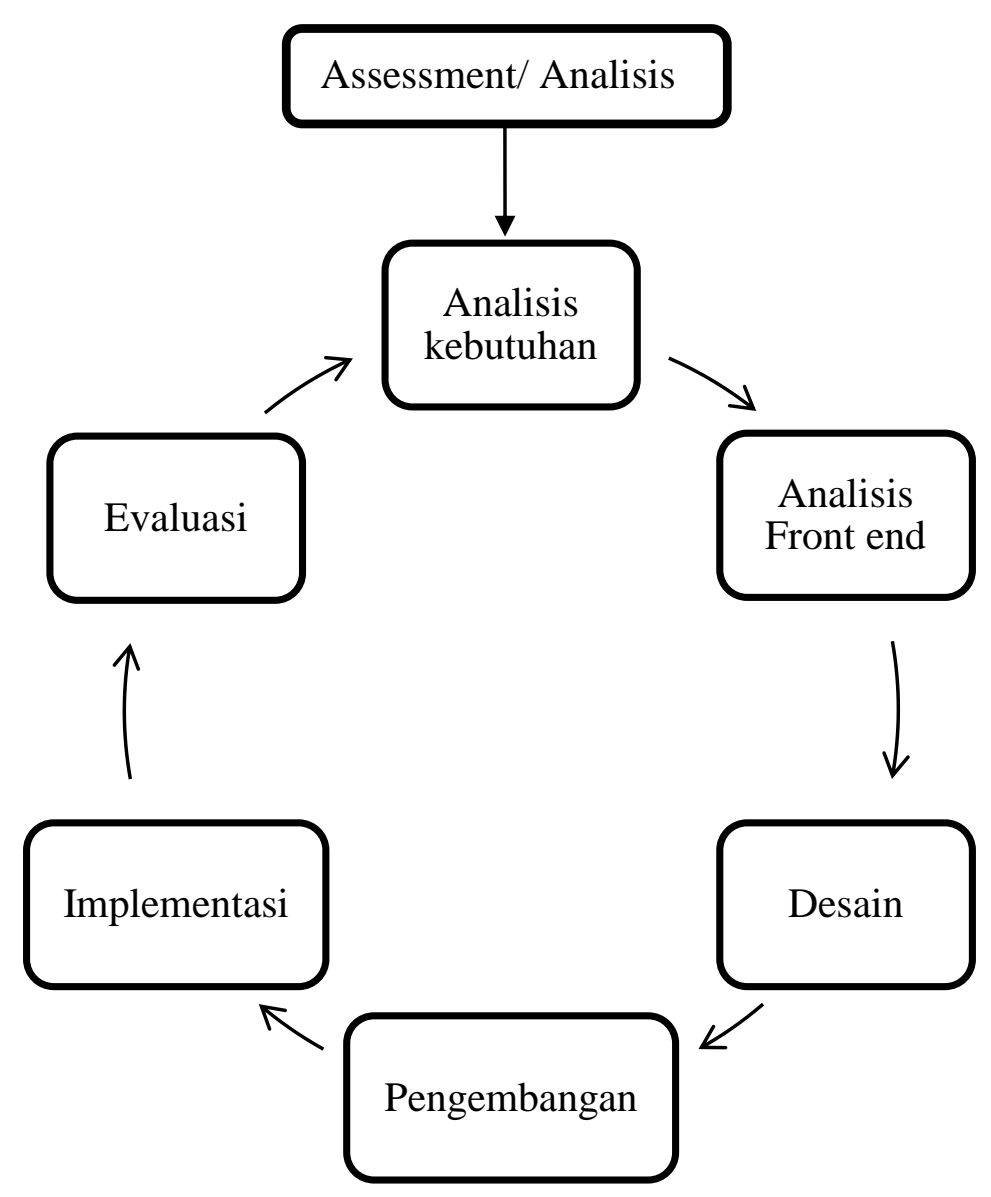

Gambar 1. Alur Penelitian dan Pengembangan (Research and Development) 
Subjek uji coba dalam penelitian ini menggunakan ahli materi, ahli media, uji coba perorangan, uji coba kelompok kecil dan uji coba kelompok besar. Instrumen pengumpulan data yang digunakan adalah angket dan tes, Instrumen pengumpulan data menggunakan angket ini terdiri dari angket tertutup dan terbuka, adanya penggunaan angket tertutup ini untuk mendapatkan data secara kuantitatif dan test bertujuan untuk mengetahui keefektifan multimedia yang dikembangkan. Teknik analisis data yang digunakan adalah deskriptif kualitatif dan deskriptif kuantitatif. Tabel 1 menunjukkan langkah-langkah yang dilakukan dalam mengembangkan multimedia interaktif.

Tabel 1. Langkah-langkah Pengembangan Multimedia Interaktif

\begin{tabular}{|l|l|}
\hline Analisis kebutuhan & $\begin{array}{l}\text { Need Assessment atau analisis kebutuhan } \\
\text { dimulai dari pengidentifikasian masalah yang } \\
\text { dilakukan oleh peneliti dengan cara melakukan } \\
\text { observasi lapangan untuk mengetahui kondisi } \\
\text { nyata dilapangan. Need assessment ini } \\
\text { dilakukan dengan cara interview terhadap guru } \\
\text { serta siswa untuk mngetahui permasalahan yang } \\
\text { ada sehingga dapat mencari solusi yang } \\
\text { diharapkan dari permasalahan yang ada. }\end{array}$ \\
\hline
\end{tabular}

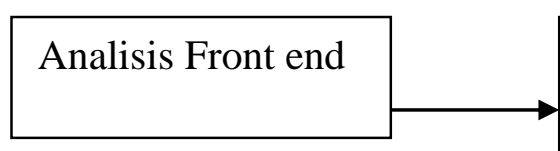

Tahap ini merupakan bagian dari tahap need assessment (penilaian kebutuhan) yang bertujuan untuk memperoleh data yang lebih akurat, dalam Analisis Front-End ada sembilan tahapan yang harus dilakukan 1) analisis peserta; 2) analisis teknologi; 3) analisis situasi; 4) analisis tugas; 5) Analisis Insiden-kritis; 6) Analisis Tujuan; 7) Analisis media; 8) Analisis data yang ada; 9) Analisis Biaya.

\begin{tabular}{|l|l|}
\hline Desain & $\begin{array}{l}\text { Tahap desain merupakan tahap perencanaan } \\
\text { pembuatan produk multimedia yang akan } \\
\text { dikembangkan. Pada tahap desain ini di lakukan } \\
\text { tahap-tahap antara lain jadwal, tim proyek, } \\
\text { spesifikasi media, struktur materi, kontrol } \\
\text { konfigurasi dan siklus review }\end{array}$ \\
\hline
\end{tabular}




\begin{tabular}{|l|l|}
\hline Pengembangan & $\begin{array}{l}\text { Tahap ini merupakan tahap pembuatan produk } \\
\text { yang telah di susun pada tahap desain sehingga } \\
\text { dapat menghasilkan multimedia interaktif } \\
\text { pembelajaran. Proses pengembangan ini } \\
\text { dilakukan mulai dari membuat flowchart ke } \\
\text { dalam storyboards, memasang komponen- } \\
\text { komponen, melakukan review, melakukan } \\
\text { perbaikan sehingga produk layak untuk } \\
\text { digunakan dalam proses pembelajaran. }\end{array}$ \\
\hline
\end{tabular}

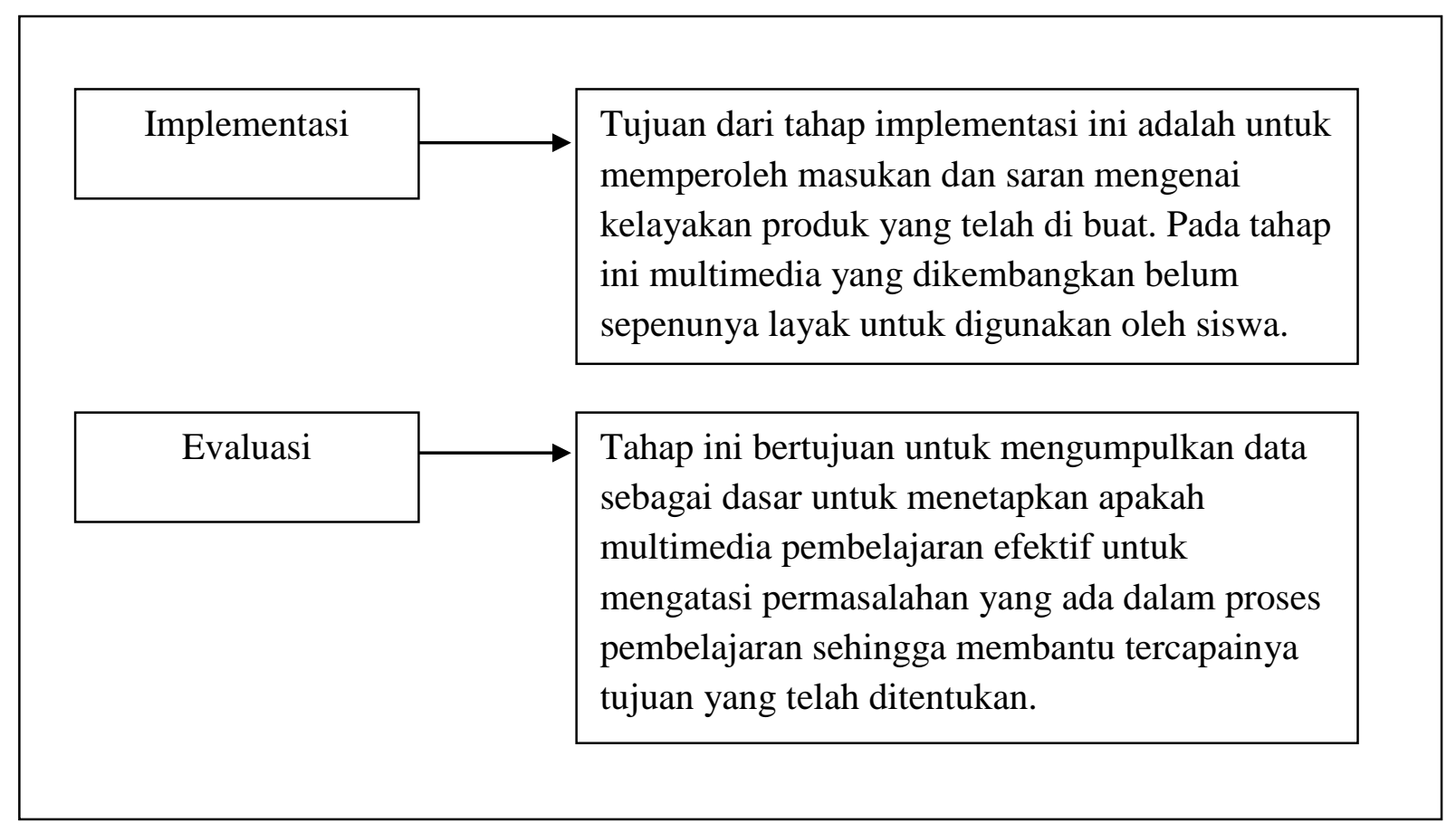

\section{HASIL DAN PEMBAHASAN}

\section{Hasil Pengembangan bahan ajar}

Uji coba untuk ahli materi ini dilakukan oleh peneliti untuk mengetahui apakah materi yang dicantumkan dalam multimedia interaktif ini telah sesuai dan telah valid untuk di sampaikan kepada siswa dalam kegiatan belajar mengajar. Hasil dari analisis data yang diperoleh dari ahli materi di peroleh hasil rata-rata presentase sebesar $89 \%$.

Uji coba ahli media ini bertujuan untuk mengetahui apakah multimedia Interaktif yang telah dikembangkan telah layak untuk digunakan sebagai media dalam proses belajar mengajar. Dalam uji coba ini dibutuhkan 1 orang ahli media untuk memvalidasi. Hasil dari analisis data yang diperoleh dari ahli media di peroleh hasil rata-rata presentase sebesar $98 \%$.

Audience/Siswa Perorangan bertujuan untuk mengetahui kekurangan multimedia interaktif yang tidak terdeteksi saat pembuatan produk. Dalam uji coba ini dilakukan oleh 3 orang siswa kelas XI Akuntansi di SMK Muhammadiyah 2 Malang yang memiliki kemampuan di atas, sedang dan 
dibawah rata-rata, Hasil dari Analisis Data Audience/Siswa Perorangan di peroleh hasil rata-rata presentase sebesar $81,33 \%$.

Uji coba kelompok kecil ini bertujuan untuk mengetahui kekurangan multimedia interaktif yang tidak terdeteksi pada saat uji coba data Audience/Siswa Perorangan. Dalam uji coba ini dilakukan oleh 5 orang siswa kelas XI Akuntansi di SMK Muhammadiyah 2 Malang, Hasil dari Analisis Data Audience/Siswa kelompok kecil di peroleh hasil rata-rata presentase sebesar $86,67 \%$.

Uji coba kelompok besar ini bertujuan untuk mengetahui apakah produk yang telah direvisi ini dapat mempermudah siswa dalam pemahaman materi sehingga dapat dikatakan layak untuk digunakan sebagai media dalam proses belajar mengajar. Dalam uji doba kelompok besar ini di lakukan oleh siswa kelas X Akuntansi di SMK Muhammadiyah 2 Malang yang terdiri dari 14 siswa. Hasil dari Analisis Data Audience/Siswa Lapangan/kelompok besar di peroleh hasil rata-rata presentase sebesar $88,76 \%$. Berdasarkan hasil tersebut dapat di artikan bahwa multimedia interaktif pada mata pelajaran akuntansi pokok bahasan siklus akuntansi perusahaan jasa termasuk dalam kategori sangat layak untuk digunakan dalam kagiatan belajar mengajar.

Hasil belajar siswa setelah menggunakan multimedia interaktif dapat di lihat dari hasil pretest yang diberikan kepada siswa sebelum menggunakan multimedia interaktif, postes yang diberikan setelah siswa menggunakan multimedia interaktif. Berdasarkan hasil perhitungan dapat di ketahui bahwa gain score pretes dan postes pada uji coba audience/siswa kelompok besar adalah 0.3. Gain Score sebesar 0.3 menunjukkan bahwa nilai tambah yang dicapai siswa dalam uji coba audience/siswa kelompok besar ini termasuk dalam kategori sedang.

\section{Aspek Teknis}

Dari aspek ini diperoleh masukan tentang multimedia interaktif sebagai berikut : memperjelas maksud dari petunjuk penggunaan, memperbesar font dalam multimedia interaktif, mengurangi gambar dan menata kembali gambar agar tidak menganggu siswa dalam belajar, dan memberikan feedback berupa penjelasan mengenai jawaban soal pada soal pilihan ganda.

Secara keseluruhan diperoleh pendapat bahwa aspek teknis (persyaratan sistem, navigasi dan design) pada multimedia interaktif pada mata pelajaran akuntansi pokok bahasan siklus akuntansi perusahaan jasa ini telah layak dan dapat digunakan sebagai bahan ajar dalam kegiatan belajar mengajar.

\section{Aspek Edukatif}

Validasi untuk ketetapan aspek edukatif dari multimedia interaktif adalah tentang konten materi serta soal-soal yang ada. Dalam aspek edukatif ini diperoleh masukan tentang multimedia interaktif sebagai berikut : memperbanyak soal dalam multimedia untuk evaluasi yang lebih banyak dan komprehensif, memberikan soal pengayaan dan membuat soal dengan tingkat kesulitan yang berbeda beda. 
Secara umum, atas pengembangan multimedia interaktif ini telah dinilai valid oleh validator dan layak digunakan sebagai bahan ajar dalam kegiatan belajar mengajar.

\section{SIMPULAN}

Media merupakan salah satu alat yang cukup mendukung dalam kegiatan belajar mengajar karena siswa dapat mengoperasikan sendiri multimedia interaktif tersebut, selain itu dengan tampilan yang menarik dan materi yang dilengkapi dengan gambar dan video yang mendukung materi yang di sampaikan, sangat membantu dalam kegiatan belajar mengajar. Dengan segala kelebihan yang dimiliki oleh multimedia interaktif ini diharapkan dapat menjadi sumber belajara bagi siswa dan dapat digunakan sebagai alternatif dalam meningkatkan motivasi belajar siswa sehinggadapat tercapinya tujuan pembelajaran.

Hasil dari pengembangan ini adalah multimedia interaktif yang berisi materi siklus akuntansi perusahaan jasa. Multimedia ini telah di validasi oleh ahli media, ahli materi, uji coba perorangan, uji coba kelompok kecil dan uji coba kelompok besar. Media yang telah selesai di revisi akan dimasukkan kedalam CD agar siswa dapat menggunakan dan memanfaatkan media tersebut kapan saja dan dimana saja. Secara keseluruhan multimedia interaktif yang telah dikembangkan telah layak untuk digunakan dalam peroses pembelajaran.

\section{DAFTAR RUJUKAN}

Arsyad. 2014. Media Pembelajaran. Jakarta: RajaGrafindo Persada Danim, Sudarwan. 2008. Media Komunikasi Pendidikan. Jakarta: Bumi Aksara

Lee, W \& Owens, D, L. 2004. Multimedia Based Instructional Design, SecondEducation.United States of America: Jhon Wiley \&Sonc, Inc

Tirtarahardja, Umar., Sulo, La, S.L. 2005. Pengantar Pendidikan. Jakarta : PTRineka Cipta

Winarno, Agung. 2014. Pengantar Pendidikan. Malang: Universitas NegeriMalang 